\title{
GROWTH PERFORMANCE OF TWO MANGO (Mangifera indica L.) CULTIVARS IN HIGH CALCAREOUS SANDY SOIL
}

\author{
O. A. Zagzog*; A. E. Melouk** and Sh. M. Metwally*** \\ * Plant Production Department, Institute of Efficient Productivity, Zagazig Univ., Egypt. \\ ** Horticulture Department, Faculty of Agriculture, Suez Canal University, Egypt. \\ *** Soil \& Water Department, Institute of Efficient Productivity, Zagazig University, \\ Egypt.
}

\section{ABSTRACT}

Two factorial experiments ( 2 X 5) were conducted at greenhouse of the Experimental Farm of Ismailia Agriculture Faculty, Suez Canal Univ. Egypt during 2007 and 2008 seasons to assess the growth performance and nutrients uptake efficiency of 13-mounth-old seedlings of two common mango cvs (Zebda and Succary) grown in a sandy soil under four levels of $\mathrm{CaCO}_{3}(10,15,20$ and $25 \%$ ), beside the native content of $0.29 \%$ as control.

Differential ability of the two tested mango cvs to tolerate lime was detected since, Succary cv exhibited high sensitivity compared to Zebda cv. Presence of lime up to $10 \%$ significantly depressed plant height, leaves number/plant, average leaf area and total leaf area/plant, as well as leaves, stems, roots and total dry weights/ plant of the two cultivars. Depression in vegetative growth parameters and dry weights with upraising soil lime content was more pronounced in Succary cv than Zebda cultivar.

Zebda $\mathrm{cv}$ had the highest uptake efficiency of $K$ and $C a$ as shown by their concentrations in leaf tissues. While, foliar concentrations of $N$ and $\mathrm{Zn}$ appeared an opposite trend. There is an insignificant differences between the two cvs in foliar $P$ and Fe concentrations.

Regardless of mango $\mathrm{cv}$, high soil lime content drastically reduced foliar nutrients concentrations except Calcium. It seems that $\mathrm{cv}$ Zebda is the most adaptable to overcome severity conditions of highly calcareous soil, thus it can be recommended as a lime-tolerant mango rootstock. More, long-term intensive physiological and genetic studies are needed to confirm this result, and to test wide range of mango cultivars under large scale of field conditions.

Key words: Growth performance, mango cultivars, Mangifera indica L., high calcareous, sandy soil .

\section{INTRODUCTION}

Mango (Mangifera indica L.) is one of the most popular fruit crops in Egypt and in many countries of the world. Mango has become naturalized and adapted throughout tropics and subtropics regions. Mango industry is based on four main uses: fruit, 
flavoring, medicinal and timber. Additionally, mango plays an important role in the diet and cuisine of many diverse cultures (Bally, 2006). According to Anonymous (2008), the total area occupied by mango trees reached 204284 faddans with total production of 466436 tons.

The majority of commercial mango nurseries used Succary cv as a rootstock of new mango cultivars. Many commercial mango cultivars have been grafted on seedling rootstocks that are well adapted to cultivation under specific environmental and soil conditions. Mango trees are tolerant a wide range of soils; i.e., alkaline, calcareous and heavy clay soils. But, production is best on well drained sandy or gravelly soils that dry out rapidly after wetting which forcing trees into a dormant period which was essential for heavy flowering. The most favorable soil $\mathrm{pH}$ for growing and fruiting mango trees is between 5.5-7.5, but the trees grow outside this range (Campbell et al., 2002).

Calcareous soils occur naturally in arid and semiarid regions. Unfortunately, mango industry is concentrated in these regions (Schaffer et al., 2006). The abundant accumulation of free $\mathrm{CaCO}_{3}$ (lime) in calcareous soils negatively affects many soil properties, thus induced decline growth, nutritional status and yield of many fruit crops including mango (Zude-Sasse and Schaffer, 2000). The moisture and nutrients deficiency as well as the susceptibility for surface crusting are the main factors limited calcareous soils productivity (White, 2005). Calcareous soils cover more than $30 \%$ of the earth surface, and their $\mathrm{CaCO}_{3}$ content varies from a few percent; i.e., 8-10\% to a very high percent; i.e., 95\% (Imas, 2000). Hagin and Tuker (1982) defined calcareous soil as a soil that its extractable $\mathrm{Ca}$ and $\mathrm{Mg}$ levels exceed the cation exchange capacity.

Under Egyptian conditions, calcareous sandy soils cover numerous faddans located mainly in the northern coastal regions, and accounts more than $20 \%$ of the agricultural extension area. Reported symptoms of impaired nutrition in calcareous soils were chlorosis and stunted plant growth. This is attributed to high soil $\mathrm{pH}(7.5-8.5)$ and reduction soil nutrient availability, while direct physiological and biochemical systems toxicity of bicarbonate ions $\left(\mathrm{HCO}_{3}{ }^{-}\right)$are much less likely (Imas, 2000). Presence of $\mathrm{CaCO}_{3}$ affects, directly or indirectly, the chemistry and availability of $\mathrm{N}, \mathrm{P}, \mathrm{Mg}, \mathrm{K}, \mathrm{Mn}$, $\mathrm{Zn}, \mathrm{Cu}$ and $\mathrm{Fe}$ ( White, 2005).

Nutrients deficiency in many fruit crops grown under arid-calcareous sandy soil conditions has been reported by (Cinelli et al., 1995). Gruber and Kosegarten (2002) reported that leaf chlorosis induced by Fe deficiency was the main nutritional disorder of vine orchards grown on calcareous soils. Peach susceptibility to lime induced chlorossis was higher when trees were grafted on seedlings of Prunus persica than almond peach hybrids (Shi and Byrne, 1995). Zuo et al. (2007) recorded the same conclusion for peanut plants grown on calcareous soils under Chinese conditions.

The polyembryonic mango cv 13-1 has been tested since the early 1960's in various states of America for its tolerance to calcareous soil conditions. It has grown so well in sandy soils contain medium lime content $\left(15 \% \mathrm{CaCO}_{3}\right)$. It has been adopted as the standard rootstock in commercial plantings in limestone regions (Bally, 2006). 
Using $\mathrm{CaCO}_{3}$-tolerant rootstocks or varieties is the first strategy to grow mango successfully on extremely calcareous soils. In addition, mango is the most promising fruit crop for planting in the newly reclaimed calcareous sandy soils of Egypt. However, lime-tolerance of Egyptian mango cultivars is not understood yet. Therefore, the present study aimed to assess the growth performance and nutrients uptake efficiency of 7mounth-old seedlings of two common mango cultivars (Zebda and Succary) grown in a sandy soil under additional quantities of free $\mathrm{CaCO}_{3}$ with 4 levels of 10, 15, 20 and 25\%, beside the origin content of $0.29 \%$.

\section{MATERAILS AND METHODS}

The lime-tolerance of two Egyptian mango (Mangifera indica L.) cultivars; (Zebda and Succary) were investigated in two greenhouse experiments conducted at the Experimental Farm of Ismailia Agriculture Faculty, Suez Canal University, during 2007 and 2008 seasons. The used experimental soil was very light sandy texture and the initial values of physical and chemical properties are shown in Table 1. According to Jaiswal (2004), the used soil was deficient in the most available macro- and micro-nutrients.

Table: Initial values of some physical and chemical properties of the used soil.

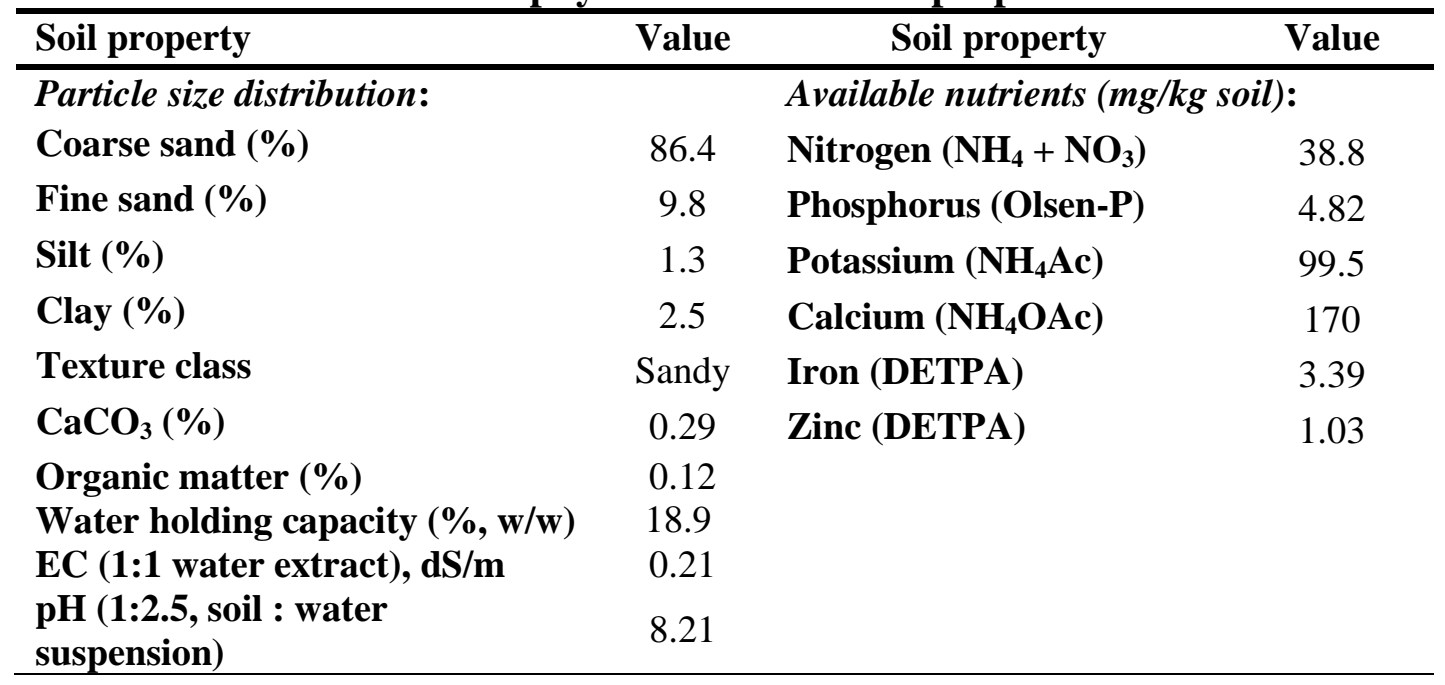

Ten treatments representing all possible combinations between the two tested mango cultivars (Zebda and Succary) and four soil lime levels (10, 15, 20 and 25\% added to the soil as $\left.\mathrm{CaCO}_{3} \%\right)$ compared with native one $(0.29 \%)$ were evaluated in this study. The treatments were set up in a factorial experiment between mango cultivars and $\mathrm{CaCO}_{3}$ percentage in a complete randomized block design with three replicates for each treatment. Each replicate was represented as ten seedlings, one seedling/ pot, so the total number of pots (seedlings) was $300(2 \times 5 \times 3 \times 10)$. 
Surface sandy soil samples $(0-30 \mathrm{~cm}$ depth) were collected, air dried and passed through a 2-mm sieve. The calculated amounts of $\mathrm{CaCO}_{3}$ were firstly spread on soil, and then thoroughly mixed before the use in filling $3.5 \mathrm{~L}$ plastic pots.

On March $1^{\text {st }}$ for the two tested seasons, uniform seven-month-old mango seedlings of Zebda and Succary cvs, which previously propagated (on September $1^{\text {st }}$ of the previous season) by vegetative embryos were transplanted into plastic pots $(30 \mathrm{~cm})$ filled with $4 \mathrm{~kg}$ sandy soil containing the designed lime concentrations. All treatments were watered to keep the soil moisture at about $70 \%$ of its holding capacity and were monthly received fertilizer solution during the growing season accounted for a total of (mg/pot) $1092 \mathrm{~N}, 158 \mathrm{P}, 792 \mathrm{~K}, 9.6 \mathrm{Fe}$, and 2.6 for each of $\mathrm{Cu}, \mathrm{Zn}$, and $\mathrm{Mn}$. The other common agricultural practices of growing mango seedlings were applied when ever needed as the same that recommended for Ismailia district..

\section{Recorded data}

On September $1^{\text {st }}$, at the end of the two experimental growing seasons, the thirteen months old plants were subjected to determination growth performance and nutrients uptake efficiency. Additionally, changes in soil $\mathrm{pH}$ and residual plant-available nutrients were estimated.

Growth performance was recorded as plant height $(\mathrm{cm})$, leaves number/ plant. Also, average leaf area $\left(\mathrm{cm}^{2}\right)$ was determined, using Planmeter set, and then total leaf area $\left(\mathrm{cm}^{2}\right) /$ plant was calculated by multiplying average leaf area by leaves number/ plant. In addition, plants were destructively harvested and divided into leaves, stems and roots. Then, were dried in a ventilated oven at $70{ }^{\circ} \mathrm{C}$ for $72 \mathrm{~h}$ and each organ (leaves, stems and roots) dry weight was recorded.

To determine nutrients uptake efficiency, a randomly dry leaf samples represented treatments were ground in a metallic mill to pass a $0.2 \mathrm{~mm}$ mesh. Leaf powder $\left(0.2 \mathrm{~g}\right.$ for each) was wet-digested in acidic mixture $\left(4 \mathrm{H}_{2} \mathrm{SO}_{4}: 1 \mathrm{HClO}_{4}\right)$ at $420^{\circ} \mathrm{C}$ for chemical analysis of N, P, K, Ca, Fe and Zn. Also, a set of soil sample consists of three replicates for each treatment was collected after seedlings harvesting in the second season, then was prepared for determinations of soil $\mathrm{pH}$ and residual plant available $\mathrm{N}$, $\mathrm{P}, \mathrm{K}, \mathrm{Fe}$ and $\mathrm{Zn}$. All these determinations were conducted according to the recommended procedures described by Jaiswal (2004).

\section{Statistical analysis}

The collected data were statistically analyzed according to Snedecor and Cochran (1990). Mean separation was done using Duncan's multiple range test at $5 \%$ level (Duncan, 1958).

\section{RESULTS AND DISCUSSION}

\section{Growth performance:}

Seedling growth performance, as vegetative traits and plant organs dry weights, of the two mango cvs grown on a calcareous sandy soil during 2007 and 2008 seasons is shown in Tables 2 and 3. 
Table 2. Vegetative growth of 13 months old mango seedlings grown on a sandy soil as affected by cultivar, soil lime $\left(\mathrm{CaCO}_{3} \%\right)$ and their interaction during 2007 and 2008 seasons

\begin{tabular}{|c|c|c|c|c|c|c|c|c|}
\hline \multirow[t]{2}{*}{ Treatments } & \multicolumn{2}{|c|}{$\begin{array}{l}\text { Plant height } \\
\text { (cm) }\end{array}$} & \multicolumn{2}{|c|}{$\begin{array}{c}\text { Leaves } \\
\text { No./plant }\end{array}$} & \multicolumn{2}{|c|}{$\begin{array}{l}\text { Average leaf } \\
\text { area }\left(\mathrm{cm}^{2}\right)\end{array}$} & \multicolumn{2}{|c|}{$\begin{array}{c}\text { Total leaf } \\
\text { area/plant } \\
\left(\mathrm{cm}^{2}\right)\end{array}$} \\
\hline & 2007 & 2008 & 2007 & 2008 & 2007 & 2008 & 2007 & 2008 \\
\hline \multicolumn{9}{|l|}{ Mango Cultivar: } \\
\hline Zebda & $52.0 \mathrm{a}$ & $57.3 \mathrm{a}$ & $46.3 \mathrm{a}$ & $36.9 \mathrm{a}$ & $27.9 \mathrm{a}$ & $35.1 \mathrm{a}$ & $1352 \mathrm{a}$ & $1364 \mathrm{a}$ \\
\hline Succary & $47.9 \mathrm{~b}$ & $46.8 \mathrm{~b}$ & $19.4 \mathrm{~b}$ & $19.7 \mathrm{~b}$ & $31.8 \mathrm{a}$ & $37.1 \mathrm{a}$ & $740 \mathrm{~b}$ & $860 \mathrm{~b}$ \\
\hline \multicolumn{9}{|c|}{ Soil lime $\left(\mathrm{CaCO}_{3} \%\right):$} \\
\hline (Native) 0.29 & $63.9 \mathrm{a}$ & $65.7 \mathrm{a}$ & $42.6 \mathrm{a}$ & $38.6 \mathrm{a}$ & $54.8 \mathrm{a}$ & $52.7 \mathrm{a}$ & $2158 \mathrm{a}$ & $1986 \mathrm{a}$ \\
\hline 10 & $50.4 \mathrm{~b}$ & $63.9 \mathrm{a}$ & $45.6 \mathrm{a}$ & $32.4 \mathrm{~b}$ & $36.4 b$ & $43.5 \mathrm{ab}$ & $1511 b$ & $1363 b$ \\
\hline 15 & $48.3 \mathrm{bc}$ & $49.4 \mathrm{~b}$ & $29.0 \mathrm{~b}$ & $30.5 b$ & $20.9 c$ & $38.5 \mathrm{abc}$ & $626 c$ & $1246 b$ \\
\hline 20 & $43.2 \mathrm{c}$ & $41.1 \mathrm{c}$ & $26.6 b$ & $21.2 \mathrm{c}$ & $16.7 \mathrm{c}$ & $24.8 \mathrm{bc}$ & $456 c$ & $543 c$ \\
\hline 25 & $44.1 \mathrm{c}$ & $40.2 \mathrm{c}$ & $20.4 \mathrm{c}$ & $18.9 \mathrm{c}$ & $20.4 \mathrm{c}$ & $21.0 \mathrm{c}$ & $481 \mathrm{c}$ & $419 \mathrm{c}$ \\
\hline \multicolumn{9}{|c|}{ Interactions (Cultivar $\times$ Soil lime as $\left(\mathrm{CaCO}_{3} \%\right)$ : } \\
\hline Zebda $\times 0.29$ & $64.2 \mathrm{a}$ & $70.9 \mathrm{a}$ & $55.0 \mathrm{~b}$ & $45.6 \mathrm{a}$ & $40.4 \mathrm{bc}$ & $44.9 \mathrm{a}$ & $2205 a$ & $2057 \mathrm{a}$ \\
\hline$\times 10$ & $58.8 \mathrm{a}$ & $71.1 \mathrm{a}$ & $71.9 \mathrm{a}$ & $41.1 \mathrm{a}$ & $30.2 \mathrm{bcd}$ & $34.9 \mathrm{a}$ & $2191 \mathrm{a}$ & $1436 \mathrm{a}$ \\
\hline$\times 15$ & $48.9 b$ & $58.3 \mathrm{~b}$ & $40.8 c$ & $44.4 \mathrm{a}$ & $22.3 \mathrm{de}$ & $41.7 \mathrm{a}$ & $916 b$ & $1901 \mathrm{a}$ \\
\hline$\times \mathbf{2 0}$ & $42.3 b$ & $45.0 \mathrm{c}$ & $36.8 \mathrm{~cd}$ & $30.0 \mathrm{~b}$ & $17.3 \mathrm{de}$ & $26.8 \mathrm{a}$ & $647 \mathrm{bcd}$ & $799 a$ \\
\hline$\times 25$ & $46.2 \mathrm{~b}$ & $41.1 \mathrm{~cd}$ & $27.2 \mathrm{e}$ & $23.5 \mathrm{c}$ & $29.2 \mathrm{~cd}$ & $27.3 \mathrm{a}$ & $802 b c$ & $628 \mathrm{a}$ \\
\hline Succary $\times 0.29$ & $63.6 \mathrm{a}$ & $60.6 \mathrm{~b}$ & $30.3 \mathrm{de}$ & $31.6 \mathrm{~b}$ & $69.2 \mathrm{a}$ & $60.6 \mathrm{a}$ & $2110 a$ & $1916 a$ \\
\hline$\times 10$ & $42.1 \mathrm{~b}$ & $56.8 \mathrm{~b}$ & $19.3 \mathrm{f}$ & $23.7 \mathrm{c}$ & $42.6 \mathrm{~b}$ & $52.0 \mathrm{a}$ & $831 b c$ & $1291 \mathrm{a}$ \\
\hline$\times 15$ & $47.7 \mathrm{~b}$ & $40.5 \mathrm{~cd}$ & $17.2 \mathrm{f}$ & $16.6 \mathrm{~d}$ & $19.4 \mathrm{de}$ & $35.4 \mathrm{a}$ & $336 \mathrm{~cd}$ & $592 \mathrm{a}$ \\
\hline$\times 20$ & $44.1 \mathrm{~b}$ & $37.2 \mathrm{~d}$ & $16.5 \mathrm{f}$ & $12.4 \mathrm{~d}$ & $16.1 \mathrm{e}$ & $22.8 \mathrm{a}$ & $264 d$ & $288 \mathrm{a}$ \\
\hline$\times 25$ & $42.0 \mathrm{~b}$ & $39.3 \mathrm{~cd}$ & $13.7 \mathrm{f}$ & $14.4 \mathrm{~d}$ & $11.7 \mathrm{e}$ & $14.7 \mathrm{a}$ & $160 d$ & $211 \mathrm{a}$ \\
\hline
\end{tabular}

Means having same alphabetical letter (s) within each column did not significantly differ according to Duncan's Multiple Range Test at 5\% level.

\subsection{Vegetative growth:}

\section{1.1. Effect of mango cultivar:}

Results in Table 2 show significant differences between the two mango cvs for most vegetative growth attributes. Zebda cv had taller plants than that of Succary cv, and this was true in both seasons. Also, Zebda cv significantly exhibited higher leaves number/ plant and hence higher total leaf area/plant than Succary cv during the two seasons. While, average leaf area was almost the same for the two cvs in the two growing seasons without significant differences. However, differences between the two mango cvs in their vegetative growth parameters are varietal differences that go back to genetic composition. In this respect, Bally (2006) reported that growth vigor of a mango $\mathrm{cv}$ is an inherent property ascribing to the genetic make up of the cultiver. Outweigh of a mango cv in growth traits especially the area of photosynthetic leaves indicates its higher capacity for accumulating photosynthesis. 
Table 3: Leaves, stems, roots and total dry weights per plant of 13 months old mango seedlings grown on a sandy soil as affected by cultivar, soil lime $\left(\mathrm{CaCO}_{3} \%\right)$ and their interaction during 2007 and 2008 seasons

\begin{tabular}{|c|c|c|c|c|c|c|c|c|c|c|}
\hline \multirow{3}{*}{ Treatments } & \multicolumn{10}{|c|}{ Dry weight/ seedling (g) } \\
\hline & \multicolumn{2}{|c|}{ Leaves } & \multicolumn{2}{|c|}{ Stems } & \multicolumn{2}{|c|}{ Roots } & \multicolumn{2}{|c|}{ Total } & \multicolumn{2}{|c|}{$\begin{array}{c}\text { Relative } \\
\text { total dry } \\
\text { weight }(\%)\end{array}$} \\
\hline & 2007 & 2008 & 2007 & 2008 & 2007 & 2008 & 2007 & 2008 & 2007 & 2008 \\
\hline \multicolumn{11}{|c|}{ Mango Cultivar: } \\
\hline Zebda & $45.1 \mathrm{a}$ & $44.9 \mathrm{a}$ & $31.5 \mathrm{a}$ & $28.8 \mathrm{a}$ & $28.9 \mathrm{a}$ & $28.4 \mathrm{a}$ & $105.5 \mathrm{a}$ & $102.2 \mathrm{a}$ & 100 & 100 \\
\hline Succary & $31.1 \mathrm{~b}$ & $30.4 \mathrm{~b}$ & $22.8 \mathrm{~b}$ & $22.7 b$ & $23.4 \mathrm{~b}$ & $25.2 \mathrm{~b}$ & $77.4 \mathrm{~b}$ & $78.4 \mathrm{~b}$ & 73.3 & 76.7 \\
\hline \multicolumn{11}{|c|}{ Soil lime $\left(\mathrm{CaCO}_{3} \%\right)$ : } \\
\hline $\begin{array}{r}\text { (Native) } \\
0.29\end{array}$ & $52.7 \mathrm{a}$ & $51.8 \mathrm{a}$ & $36.1 \mathrm{a}$ & $36.2 \mathrm{a}$ & $32.2 \mathrm{a}$ & $35.6 \mathrm{a}$ & $121.1 \mathrm{a}$ & $123.6 \mathrm{a}$ & 100 & 100 \\
\hline 10 & $40.5 b$ & $42.3 b$ & $28.9 b$ & $32.8 \mathrm{a}$ & $30.7 \mathrm{a}$ & $32.7 \mathrm{a}$ & $100.2 b$ & $107.9 \mathrm{~b}$ & 82.7 & 87.3 \\
\hline 15 & $38.2 b$ & $38.6 \mathrm{c}$ & $26.3 \mathrm{bc}$ & $24.1 b$ & $23.4 \mathrm{~b}$ & $26.1 \mathrm{~b}$ & $87.9 \mathrm{c}$ & $88.9 \mathrm{c}$ & 72.5 & 71.9 \\
\hline 20 & $29.8 \mathrm{c}$ & $28.9 \mathrm{~d}$ & $22.2 \mathrm{c}$ & $19.4 \mathrm{c}$ & $23.6 b$ & $21.2 \mathrm{c}$ & $75.7 \mathrm{~d}$ & $69.6 \mathrm{~d}$ & 62.5 & 56.3 \\
\hline 25 & $29.3 \mathrm{c}$ & $26.6 \mathrm{~d}$ & $22.3 \mathrm{c}$ & $16.4 \mathrm{c}$ & $20.8 \mathrm{~b}$ & $18.4 \mathrm{c}$ & $72.5 \mathrm{~d}$ & $61.4 \mathrm{e}$ & 59.8 & 49.7 \\
\hline \multicolumn{11}{|c|}{ Interactions (Cultivar $\times$ Soil lime content as $\left.\mathrm{CaCO}_{3} \%\right)$ : } \\
\hline Zebda $\times 0.29$ & $50.6 \mathrm{ab}$ & $53.3 \mathrm{a}$ & $35.5 \mathrm{ab}$ & $36.5 \mathrm{a}$ & $30.8 b$ & $37.7 \mathrm{a}$ & $117.0 \mathrm{a}$ & $127.6 \mathrm{a}$ & 100 & 100 \\
\hline$\times \mathbf{1 0}$ & $48.6 \mathrm{ab}$ & $48.7 \mathrm{ab}$ & $31.2 \mathrm{abc}$ & $34.0 \mathrm{a}$ & $37.3 \mathrm{a}$ & $34.9 \mathrm{a}$ & $117.2 \mathrm{a}$ & $117.6 \mathrm{~b}$ & 100 & 92.2 \\
\hline$\times 15$ & $45.5 \mathrm{bc}$ & $47.3 b$ & $31.2 \mathrm{abc}$ & $27.6 \mathrm{bc}$ & $24.6 \mathrm{~cd}$ & $26.2 \mathrm{a}$ & $101.4 b$ & $101.1 \mathrm{c}$ & 86.7 & 79.2 \\
\hline$\times 20$ & $41.0 \mathrm{c}$ & $39.2 \mathrm{c}$ & $30.2 \mathrm{abc}$ & $24.7 \mathrm{~cd}$ & $26.3 \mathrm{c}$ & $23.8 \mathrm{a}$ & $97.5 b$ & $87.7 d$ & 83.3 & 68.7 \\
\hline$\times 25$ & $39.8 \mathrm{c}$ & $35.8 \mathrm{c}$ & $29.2 \mathrm{bc}$ & $21.2 \mathrm{~d}$ & $25.4 \mathrm{~cd}$ & $19.7 \mathrm{a}$ & $94.5 b c$ & $76.8 \mathrm{e}$ & 80.7 & 60.1 \\
\hline Succary $\times 0.29$ & $54.9 \mathrm{a}$ & $50.2 \mathrm{ab}$ & $36.7 \mathrm{a}$ & $35.8 \mathrm{a}$ & $33.5 \mathrm{ab}$ & $33.5 \mathrm{a}$ & $125.1 \mathrm{a}$ & $119.6 \mathrm{ab}$ & 106.9 & 93.7 \\
\hline$\times 10$ & $32.4 \mathrm{~d}$ & $35.9 \mathrm{c}$ & $26.5 \mathrm{~cd}$ & $31.6 a b$ & $24.1 \mathrm{~cd}$ & $30.6 a$ & $83.1 \mathrm{~cd}$ & $98.2 \mathrm{c}$ & 71.0 & 76.9 \\
\hline$\times 15$ & $30.9 \mathrm{~d}$ & $29.9 d$ & $21.3 \mathrm{de}$ & $20.7 \mathrm{~d}$ & $22.2 \mathrm{~cd}$ & $26.0 \mathrm{a}$ & $74.5 \mathrm{~d}$ & $76.7 \mathrm{e}$ & 63.6 & 60.1 \\
\hline$\times 20$ & $18.5 \mathrm{e}$ & $18.7 \mathrm{e}$ & $14.2 \mathrm{f}$ & $14.1 \mathrm{e}$ & $20.9 d$ & $18.6 \mathrm{a}$ & $53.7 \mathrm{e}$ & $51.5 f$ & 45.8 & 40.3 \\
\hline$\times 25$ & $18.8 \mathrm{e}$ & $17.4 \mathrm{e}$ & $15.3 \mathrm{ef}$ & $11.5 \mathrm{e}$ & $16.3 \mathrm{e}$ & $17.1 \mathrm{a}$ & $50.4 \mathrm{e}$ & 46.0f & 43.1 & 36.0 \\
\hline
\end{tabular}

Means having same alphabetical letter (s) within each column did not significantly differ according to Duncan's Multiple Range Test at 5\% level.

\subsection{Effect of soil lime percent:}

Regardless of mango cv, it is evident from Table 2 that all studied growth attributes (plant height, leaves number/plant, average leaf area or total leaf area/plant) were significantly and gradually depressed with increasing soil lime content from 0.29 to 10 or to $20 \%$, and this was clearly true over the two seasons with few exceptions. But, increasing soil lime content over than $20 \%$ did not induce additional significant decreases in most cases. According to $\mathrm{Li}$ (2009) the prejudicial effects of lime $\left(\mathrm{CaCO}_{3}\right)$ on plant growth is ascribed to its role in raising soil $\mathrm{pH}$, and thus on soil nutrients availability through chemical reactions that affect the loss or fixation of almost all nutrients. Additionally, $\mathrm{CaCO}_{3}$ in calcareous soils increase concentration of $\mathrm{HCO}_{3}{ }^{-}$in soil solution. Pearce et al. (1999) set aside the direct toxicity of $\left(\mathrm{HCO}_{3}\right)^{-}$to physiological and biochemical systems of plants grown on such soils. Li (2009) reported that the celebrated symptoms of impaired plant nutrition in calcareous soils are chlorosis and stunted growth. 


\subsubsection{Effect of interaction between mango cvs and soil lime content:}

Data in Table 2 show that Zebda cv recorded the highest values represented plant height, leaves number/plant, average leaf area and total leaf area/ plant under native soil lime of $0.29 \%$ and content of $10 \%$. Raising lime concentration more than $15 \%$ resulted in gradual calm decreases in seedlings growth of Zebda cv. Succary cv is very susceptible to deleterious effects of soil lime content as its growth sharply depressed immediately when $\mathrm{CaCO}_{3}$ presence at concentration of $10 \%$ or excess.

\subsection{Dry weights:}

\subsubsection{Effect of mango cultivar:}

Data in Table 3 indicate that the two mango cvs significantly differ in their efficiencies to accumulate dry weight. Zebda cv significantly surpassed Succary cv in leaf, stem and root dry weights, and over their total dry weight/ seedling. This result confirmed the previous obtained results of vegetative growth and accurately reflecte the superiority of growth Zebda cultivar. It is well known that mango cvs; as any other plant cultivars; differ greatly in response of their genetic make up to the environmental factors that affecting developmental processes and ability to thrive benefit from the available growth factors, which in turn affect the dry matter production (Zuo et al., 2007).

\subsubsection{Effect of soil lime content:}

Irrespective of mango cv, augmentation of lime content in sandy soil bringing down the accumulation of dry matter in different seedling parts (Table 3). Leaves and roots dry weights/ plant were quite sensitive to lime concentration, where they progressively dropped with increasing soil $\mathrm{CaCO}_{3}$ content. This trend was more lucidness in the second season. Generally, the lowering in dry weight accumulation in the three seedling organs with increasing $\mathrm{CaCO}_{3}$ content in sandy soils beyond $20 \%$ was not significant, except for total dry weight/ plant. Such behavior was expected and may be attributed to the indirect impact of $\mathrm{CaCO}_{3}$ on the biosynthesis and translocation processes of metabolites to plant organs through malignant effects on nutrients uptake. Similar results were previously recorded, since Ibrahim (1995) found that intensification of soil $\mathrm{CaCO}_{3}$ content to $10 \%$ significantly decreased dry matter yield of both sorghum and barley crops growing either in sandy or clayey soils. Also, Zuo et al. (2007) found that dry matter production of peanut plant was significantly inhibited by $\mathrm{CaCO}_{3}$ at level of $18.67 \%$ compared with the control $(8.67 \%)$.

\subsubsection{Effect of interaction between mango cvs and soil lime content:}

Data presented in Table 3 show that the interactions between mango cvs and soil $\mathrm{CaCO}_{3}$ content cause significant effects on dry weight yields. This result indicates that the two mango cvs exhibited different passivity to the obnoxious effects of $\mathrm{CaCO}_{3}$. The total dry weight / plant (leaves, stems and roots ) of Succary cv seedlings were more emotion with $\mathrm{CaCO}_{3}$ concentration compared with Zebda cultivar.

Supposing total dry weight production (comprise dry weight of leaves + stems + roots) of Zebda cv under native soil lime content $(0.29)$ represents $100 \%$ of relative plant 
growth. It was decreased to 92.2, 79.2, 68.7, and 60.1\% for Zebda cv, 76.9, 60.1, 40.3, and $36.0 \%$ for Succary cv with increasing soil lime content to 10, 15, 20 and 25\%, respectively in the second season. Again, this finding asserts that Zebda cv is more adaptable for growing in highly calcareous sandy soils than Succary cv.

\section{Changes of soil $\mathrm{pH}$ and residual plant-available nutrients:}

The effect of $\mathrm{CaCO}_{3}$ content in a sandy soil on the changes of soil $\mathrm{pH}$ after 6 months of growing mango seedlings is shown in Fig. 1. The figure indicates that soil $\mathrm{pH}$ was progressively increased with increasing soil $\mathrm{CaCO}_{3}$ concentration.

It is well known that calcareous soils have enough amounts of free $\mathrm{CaCO}_{3}$, and thus they reap bad physical and chemical properties. The carbonates, due to their high reactivity and alkaline character, buffer the $\mathrm{pH}$ of most calcareous soils within the range of 7.5 to 8.5 according to the equation of: $\mathrm{CaCO}_{3}+\mathrm{H}_{2} \mathrm{O} \rightarrow \mathrm{Ca}^{2+}+\mathrm{HCO}_{3}{ }^{-}+\mathrm{OH}^{-}$. However, $\mathrm{Li}$ (2009) published that, usually, the soil $\mathrm{pH}$ is not excess 8.5 regardless of $\mathrm{CaCO}_{3}$ concentration, unless a significant quantity of $\mathrm{Na}^{+}$is present.

As for the effect of $\mathrm{CaCO}_{3}$ content in a sandy soil on changes of residual plantavailable nutrients after 6 months of growing seedlings, Fig. 2 shows that increasing $\mathrm{CaCO}_{3}$ concentration resulted in gradual increases in residual-plant available $\mathrm{K}$ and $\mathrm{Ca}$, and in contrast, caused progressive decline in remain amounts of obtainable $\mathrm{N}, \mathrm{P}, \mathrm{Fe}$ and $\mathrm{Zn}$. Calcareous soils generally have $100 \%$ base saturation, and $\mathrm{Ca}^{2+}$ is the dominant caution on the exchange complex and in soil solution (White, 2005).On the other side, the increases in residual plant available $\mathrm{Ca}^{2+}$ and $\mathrm{K}^{+}$with increasing soil lime content may be partially attributed to the conflict relationship between $\mathrm{CaCO}_{3}$ concentration and nutrients uptake efficacy by plant roots. It's meritorious to remember that $\mathrm{N}, \mathrm{P}, \mathrm{K}, \mathrm{Mn}$, $\mathrm{Zn}$ and $\mathrm{Fe}$ were supplied in adequate amounts during growing season as previously mentioned. Therefore, it is not marvelous to obtain such results concerning residual plant-available $\mathrm{Ca}^{2+}$ and $\mathrm{K}^{+}$.

The decline in residual plant-available $\mathrm{N}, \mathrm{P}, \mathrm{Zn}$ and $\mathrm{Fe}$ as a function of stepping up $\mathrm{CaCO}_{3}$ concentration in sandy soils (Fig. 2) may be caused by the effects of alkalinity conditions on the following reactions: 1 . vigorous $\mathrm{NH}_{3}$ volatilization from $\mathrm{NH}_{4}-\mathrm{N}$ under alkaline conditions of calcareous soils, 2. tied up of both native and applied $\mathrm{P}$ in highly insoluble $\mathrm{Ca}$ and $\mathrm{Mg}$ phosphates, and 3. precipitation of $\mathrm{Fe}$ and $\mathrm{Zn}$ from soil solution on the solid phase (Halajnia et al., 2009).

\section{Leaf nutrients concentration:}

\subsection{Effect of mango cultivar:}

Zebda cv plants displayed the higher leaf $\mathrm{K}$ and Ca concentrations than Succary cv (Table 4), this effect was more pronounced in 2007 season. But, foliar concentrations of $\mathrm{N}$ and $\mathrm{Zn}$ took an opposite trend, as $\mathrm{N}$ and $\mathrm{Zn}$ concentrations in leaves of Succary cv were significantly higher than that in leaves of Zebda cv in both seasons. On the other hand, the differences in leaf $\mathrm{P}$ and Fe concentrations among the tested two mango cvs 


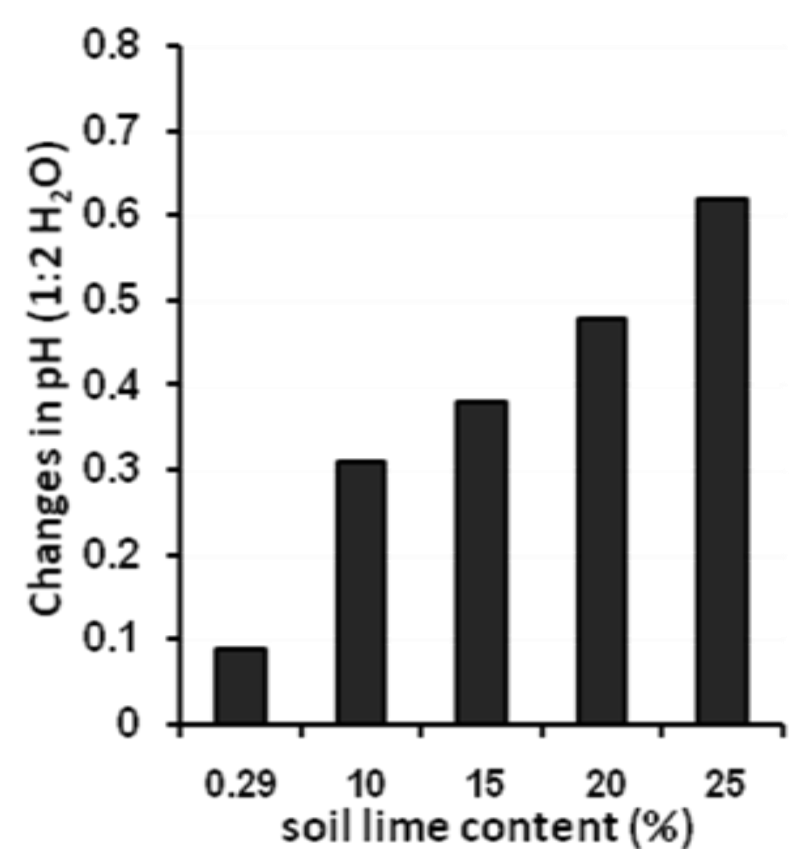

Figure 1. Changes in soil pH after 6 months of grown mango seedlings in sandy soil treated with progressive levels of $\mathrm{CaCO}_{3}$. (Changes = present values after seedlings harvest - initial values before imposing treatments).

were not significant. Generally, the seedlings of the two cvs had similar values of $\mathrm{P}$ and Fe concentrations in their leaf tissues.

It seems that the two mango cvs differed in their susceptibility to the deficiencies of obtainable $\mathrm{N}, \mathrm{K}, \mathrm{Ca}$ and $\mathrm{Zn}$, and hence in their uptake efficiencies of these nutrients from soils under calcareous conditions. Bally (2006) reported that mango cvs vary in their requirements, and abilities to absorb essential nutrients from soil, and consequently the chemical composition of their leaves. Outstanding mango cvs are often associated with better root development and distribution system allowing penetration to subsoil and increasing the ability to extract water and nutrients. In addition, root length and density is the major determinant of absorbing surface area. Though root system was not examined in this study, it expected that Zebda cv might have had better root system compared to Succary cultivar.

\subsection{Effect of soil lime percent:}

Results in Table 4 indicate that any increase in soil lime percent did depress nutrients concentration in leaves (irrespective of mango cultivar). There are antithetical relationship between soil lime percent and foliar of $\mathrm{N}, \mathrm{P}, \mathrm{K}, \mathrm{Fe}$ and $\mathrm{Zn}$ concentrations. Raising soil lime content to be calcareous lowered leaves nutrient concentrations to the critical levels despite of the adequate supplying with these nutrients through soil. Unlike, 


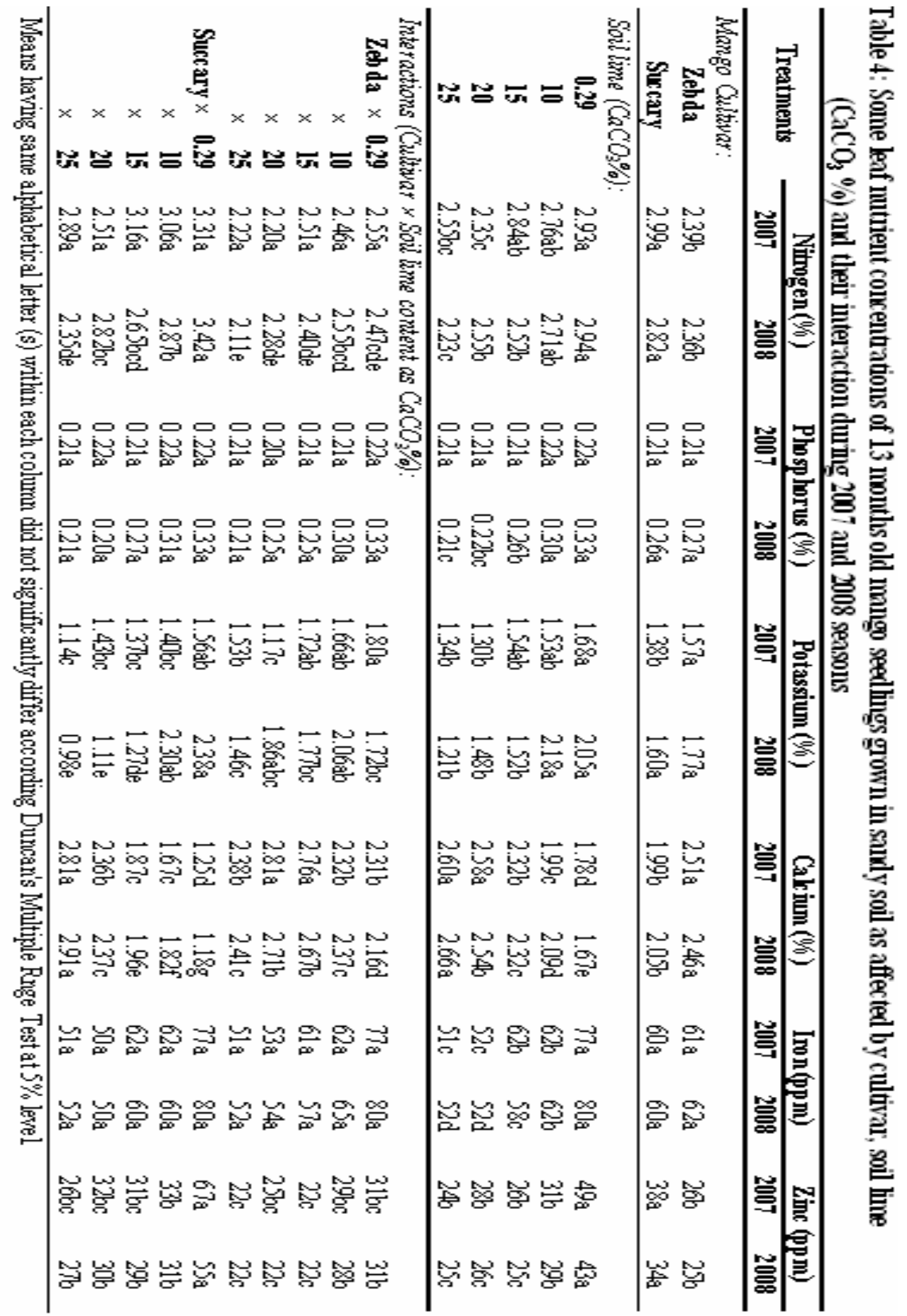



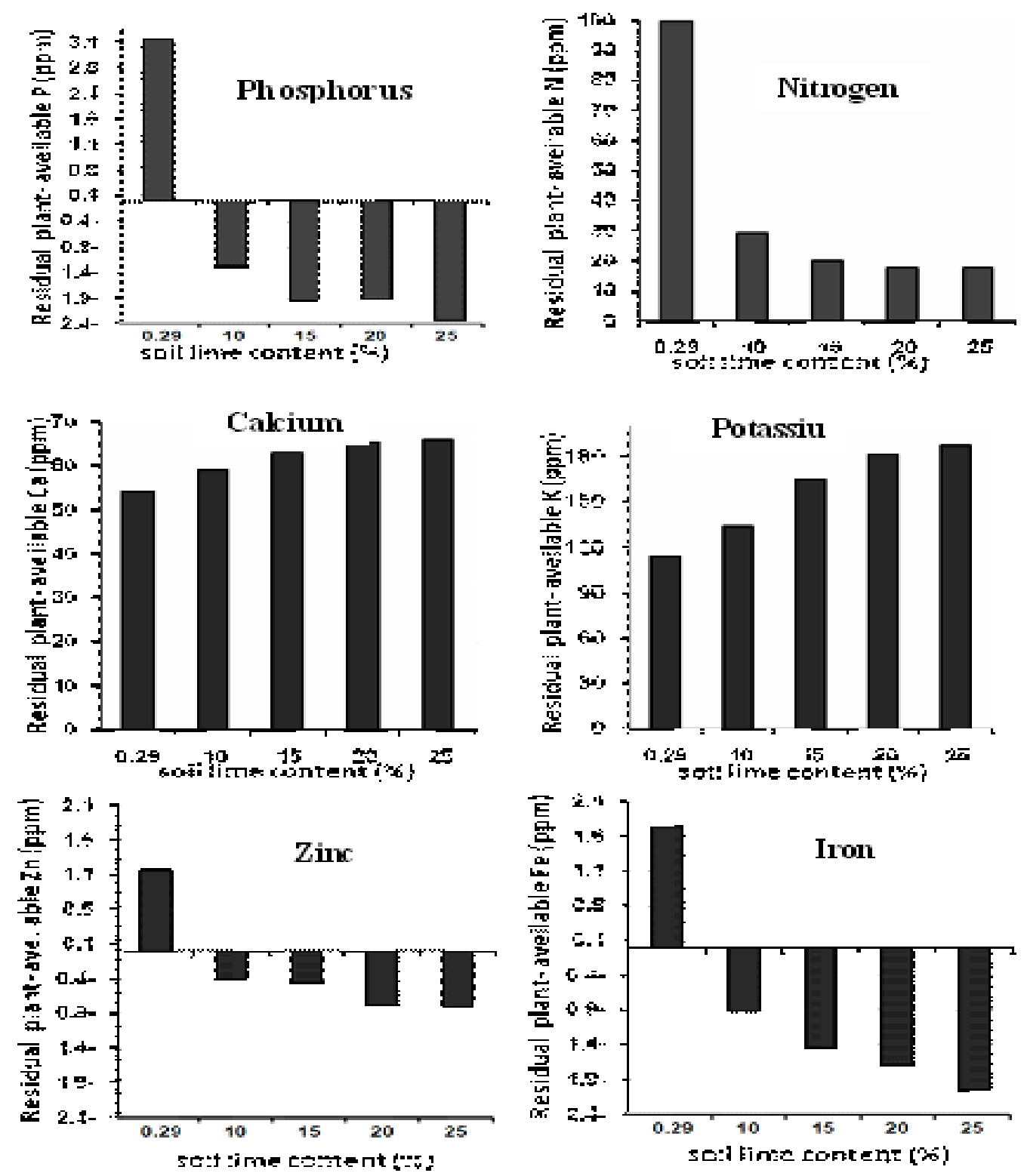

Figure 2. Changes in residual plant-available nutrients after 6 months of grown mango seedlings in sandy soil treated with progressive levels of $\mathrm{CaCO}_{3}$. (Changes = present values after seedlings harvest initial values before imposing treatments). 
increasing $\mathrm{CaCO}_{3}$ percent was associated with promotions in $\mathrm{Ca}$ concentrations in leaves of the two mango cultivars.

Nitrogen percentage in leaves was significantly decreased due to the addition of $\mathrm{CaCO}_{3}$ at rate of $10 \%$ or more (Table 4). Imas (2000) indicated that the alkaline $\mathrm{pH}$ values found in calcareous soils affect the rates of $\mathrm{N}$ transformations, which in turn can influence the efficiency of fertilizer $\mathrm{N}$ use by plants. In alkaline conditions, $\mathrm{NH}_{4}{ }^{+}$form $\mathrm{NH}_{3}$ that may be lost by volatilization.

The same trend of leaf $\mathrm{N}$ was also observed for leaf $\mathrm{P}$ percentage, differences did not attain the statistical significant level in 2007 season (Table 4). Halajnia et al. (2009) reported that after adding $\mathrm{P}$ fertilizer to a calcareous soil, it undergoes a series of chemical reactions with soil components that decrease its solubility (a process referred to as P-fixation). The mechanisms of P-fixation are: phosphate adsorption on clay minerals and $\mathrm{CaCO}_{3}$ surfaces and precipitation of Ca-phosphates. Consequently, $\mathrm{P}$ availability to plants is controlled by the application rate of soluble $\mathrm{P}$ and the dissolution and desorption of fixed phosphate.

Also, leaf $\mathrm{K}$ concentration was significantly decreased as the $\mathrm{CaCO}_{3}$ application level was increased from 0 to $10 \%$ or more (Table 4). This result confirms an antagonistic effect between $\mathrm{Ca}^{2+}$ and $\mathrm{K}^{+}$under conditions of this calcareous soil, which has primary light-textured nature and high $\mathrm{pH}$ values (Table $1 \&$ Figure 1 ). There are many reports indicating that presence $\mathrm{Ca}^{2+}$ and $\mathrm{K}^{+}$in soil in available forms in considerable amounts may interact with each other leaving more injury interaction effects on their uptake by plants. Metwally and El-Damaty (1973) found that K supplying power of calcareous soils was lower than that of alluvial soils, even when their content of non-exchangeable $\mathrm{K}$ was similar. This may stem from the high $\mathrm{Ca}$ and $\mathrm{Mg}$ content in calcareous soils, since the activity ratio $\mathrm{K} /(\mathrm{Ca}+\mathrm{Mg})$ was found to control the uptake of K, more than the K activity. Also, White, (2005) reported that high Ca levels in calcareous soils suppress $\mathrm{K}$ uptake by crops, presumably, through the competition between $\mathrm{Ca}$ and $\mathrm{K}$. For example, in grapevine, the $\mathrm{K}-\mathrm{Ca}$ antagonism impairs plant $\mathrm{K}$ uptake and results in decreased $\mathrm{K}$ concentration in the berries.

Iron concentration in leaves was progressively decreased with each increase in soil lime content (Table, 4). These results confirmed the evil effects of free $\mathrm{CaCO}_{3}$ on $\mathrm{Fe}^{2+}$ concentration in soil solution as aforementioned. The visible Fe deficiency is a common phenomenon became clear in many crops grown on calcareous soils, and this condition is known as lime-induced Fe chlorosis (Imas, 2000). The primary factor associated with $\mathrm{Fe}$ chlorosis under calcareous conditions appears to be the effect of the bicarbonate ion $\left(\mathrm{HCO}_{3}\right)^{-}$in reducing $\mathrm{Fe}$ uptake and translocation to the leaves. In some other cases, the lime-induced Fe chlorosis is related to the a high Fe level in the chlorotic leaves, which has to be somehow unavailable or immobilized inside the leaf tissue (Zuo et al., 2007). This later aspect has been called Fe chlorosis paradox, and the mechanism for Fe to be inactivated in the chlorotic leaves is still unclear (Romheld, 1997 and Imas, 2000). Salazar-Garcia (1999) reported that Fe deficiency in fruit crops can occur at both extremes of the $\mathrm{pH}$ range of agricultural soils. The following factors may contribute 
either singly or in combination to the development of chlorosis: (1) low iron supply, (2) $\mathrm{CaCO}_{3}$ in soil, (3) $\left(\mathrm{HCO}_{3}\right)^{-}$in soil or irrigation water, (4) over irrigation or waterlogged conditions, (5) high phosphate levels, (6) high levels of heavy metals, (7) low or high temperatures, (8) high light intensities, (9) high levels of $\mathrm{NO}_{3}-\mathrm{N}$, (10) imbalances in cation ratios, (11) poor soil aeration, (12) certain organic matter additions to soil, (13) viruses, and (14) root damage by nematodes and other organisms.

Results concerning decrease leaf $\mathrm{Zn}$ concentration of mango seedlings as a function of increases in soil lime content (Table 4) may be traced back to the effects of high $\mathrm{pH}$ values. At alkaline $\mathrm{pH}$ values of highly calcareous soils, very low levels of soluble $\mathrm{Zn}^{2+}$ are found, and therefore only a negligible amount can be found in the form of exchangeable $\mathrm{Zn}^{2+}$, which is available to plants. Zinc deficiency is clearly $\mathrm{pH}$ dependent, and $\mathrm{Zn}^{2+}$ concentration in solution decreases 100 -fold for each unit increase in $\mathrm{pH}$ (Lindsay, 1979). At high $\mathrm{pH}$ levels precipitates are formed, such as $\mathrm{Zn}$ hydroxides $\left[\mathrm{Zn}(\mathrm{OH})_{2}\right.$ and $\left.\mathrm{ZnCa}(\mathrm{OH})_{4}\right]$ and $\mathrm{Zn}$ carbonates $\left(\mathrm{ZnCO}_{3}\right)$.

\subsection{Effect of interaction between mango cvs and soil lime content:}

Results presented in Table 4 indicate that interactions between mango cultivar and $\mathrm{CaCO}_{3}$ application levels have significant effects on leaf $\mathrm{K}, \mathrm{Ca}$ and $\mathrm{Zn}$ concentrations in 2007 and 2008 seasons. Nitrogen percentage in mango seedling leaves was significantly affected by interaction treatments only in 2008 season. Moreover, the interaction effects on leaf $\mathrm{P}$ and $\mathrm{Fe}$ concentrations did not attain to significant differences in both growing seasons. However, obtained results are ambiguous, as it is strange to conclude a general clear trend about the highest values of foliar nutrient concentrations, where each nutrient behave own controversial trend with each mango cv under each $\mathrm{CaCO}_{3}$ level and so in each season.

Under conditions of our study, there are reasons and likelihoods for occurring such result: (1) differential ability of each mango cv; as inherent plant character; to uptake nutrients from such soil initially and additionally deficient in plant-available nutrients due to its texture nature and high $\mathrm{pH}$ that forced processes of losses, precipitation and fixation of soluble nutrients, (2) distinct degree of susceptibility of Zebda cv and Succary cv to $\mathrm{CaCO}_{3}$ concentration, and (3) inconsistent effects of soil lime content on plant-available concentrations in soil (Table 4). But, we can observe with complete confidence based on the previous studied and discussed parameters that mango Zebda cv is more tolerant to high concentrations of $\mathrm{CaCO}_{3}$ in sandy soils compared with Succary cv.

\section{CONCLUSION AND PRACTICAL IMPLICATIONS:}

Results of such study suggest that mango cv Zebda is more suitable for growing in highly calcareous soils, as it exhibited the highest values of plant growth attributes, dry weight yields, and nutrient-uptake efficiency. Also, the results lead to the conclusion that selecting lime-tolerant cultivars as rootstocks is a key for successful mango production in the extremely calcareous soils. It seems that Zebda cv is the most adaptable to overcome the severity conditions of highly calcareous soil, thus it can be recommended as a lime- 
tolerant rootstock. Further long-term intensive physiological and genetic studies are needed to confirm this result, and to test wide range of mango cultivars under large scale of field conditions particularly under situations of the newly national reclamation projects in Egypt.

\section{REFERENCES}

Anonymous 2008. The cultivated area of mango in Egypt. Statistical Report, Ministry of Agriculture, Egypt.

Bally, I.S.E. (2006). Species profiles of Pacific Island Agrofrosty. Perm. Agric. Research, 1- 25.

Campbell, R.J., C.W. Campbell, and N. Ledesma. 2002. Tropical Mangos: Growing the World's Most Delicious Fruit. Fairchild Tropical Garden, Coral Gables, Florida.

Cinelli, F., Viti, R., Byrne, D.H., Reed, D.W. 1995. Physiological characterization of two peach seedling rootstocks in bicarbonate nutrient solution. I. Root iron reduction and iron uptake. In: Abadi'a, Journal (Ed.), Iron Nutrition in Soils and Plants. Kluwer Academic Publishers, Dordrecht. 323-328

Duncan, B.D. 1958. Multiple range and Multiple F-tests. Biometrics, 11: 1-42

Gruber, B and H Kosegarten, 2002. Depressed growth of non-chlorotic vine grown in calcareous soil is an iron deficiency symptom prior to leaf chlorosis. Journal of Plant Nut. and Soil Science, 165:111-117.

Hagin, J. and B. Tuker. 1982. Fertilization of Dry Land and Irrigated Soils. Springer Verlag, New York.

Halajnia,A,G.H. Haghnia, A.Fotovat and R. Khorasani. 2009. Phosphorus fractions in calcareous soils amended with $\mathrm{P}$ fertilizer and cattle manure. Department of Soil Science, Faculty of Agriculture, Ferdowsi Univ.of Mashhad Iran Geoderma,150:209-213(Available online on: http://www.sciencedirect.com).

Ibrahim, A.H. 1995. Comparative efficiency of ordinary and triple superphosphate as $\mathrm{P}$ sources for crops grown on a sandy soil and a clay loam soil. Zagazig Journal Agric. Res., 22:1351-1364.

Imas, P. 2000. Integrated nutrient management for sustaining crop yields in calcareous soils. In symposium: Balanced nutrition of groundnut and other field crops grown on calcareous soils of India. Sept.19-22, 2000. Junagadh, India.

Jaiswal, P.C. 2004. Soil Plant and Chemical Analyses. Kalyani Publishers LudhianaNew Delhi-India (U.P.).

Li, Y. C. 2009. Calcareous Soils. In Miami-Dade County. Fact Sheet SL 183, a Publication of the Soil and Water Science Department, Florida Cooperative Extension Service, I.F.A.S., University of Florida, (Available online on : http://edis.ifas.ufl.edu/tr004).

Lindsay, W.L. 1979. Inorganic phase equilibria of micronutrients in soils. 41-47. In J.J. Mortvedt et al. (ed.) Micronutrients in Agriculture. $1^{\text {st }}$ ed. SSSA, Madison, WI. 
Metwally, A, and A. H. El-Damaty. 1973. Some studies on calcareous soils of Egypt. In: FAO soils Bulletin 21- Calcareous Soils. Food and Agriculture Organization of the United Nations, Rome.

Pearce, R.C., Y.Li and L.P. Bush. 1999. Calcium and bicarbonate effects on the growth and nutrient uptake of burley tobacco seedlings: Hydroponic culture. $J$. Plant of Nutr., 22:1069-1078.

Romheld, V. 1997. The chlorosis paradox: Fe inactivation in leaves as a secondary event in Fe deficiency chlorosis. In: $9^{\text {th }}$ International Symposium on Iron Nutrition and Interaction in Plants, Hohenheim, Stuttgart, Germany.

Salazar-García,S. 1999. Iron nutrition and deficiency: a review with emphasis in avocado (Persea americana Mill.). Revista Chapingo Serie Horticultura, 5 (2): 67-76.

Schaffer, B ; F, S. Davies and J, H. Crane. 2006. Responses of subtropical and tropical fruit trees to flooding in calcareous soil. Hort. Science, 41: 549-555.

Shi, Y.and D.H. Byrne, 1995. Tolerance of Prunus rootstocks to potassium carbonateinduced chlorosis. J. Am. Soc. Hort. Sci., 120: 283-285.

Snedecor, G.W. and W.G. Cochran .1990. Statistical Methods. $8^{\text {th }}$ Ed. Iowa State Univ. Press. Ames, Iowa, USA.

White, R.E. 2005. Principles and Practice of Soil Science: The Soil as a Natural Resource. $4^{\text {th }}$ Edition, Wiley-Blackwell.

Zude-Sasse, M and B, Schaffer . 2000. Influence of soil oxygen depletion on iron uptake and reduction in Mango (Mangifera indica L.) roots. Proc. Fla. State Hort. Soc., 113:1- 4.

Zuo Y., L. Ren ,F. Zhang and R.F. Jiang. 2007. Bicarbonate concentration as affected by soil water content controls iron nutrition of peanut plants in a calcareous soil .Plant Physiology and Biochemistry, 45: 357-364 . 
كفاءة النمو لصنفين من المانجو فى أرض رمليه مرتفعه الجير.

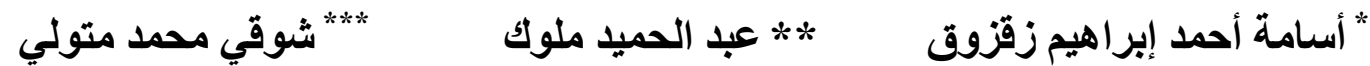

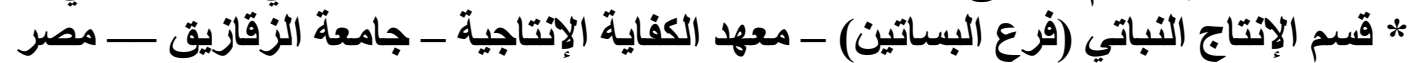

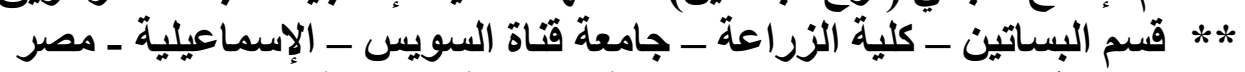

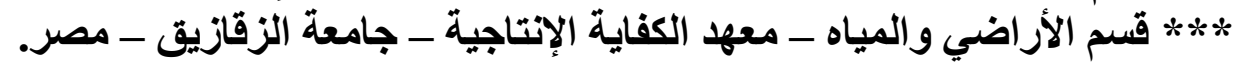

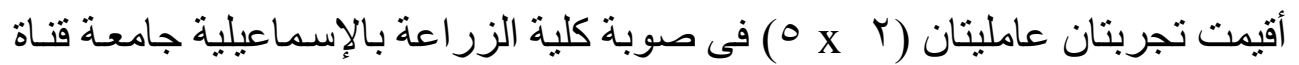

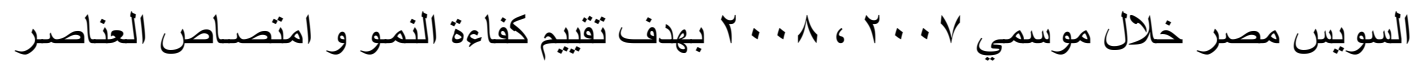

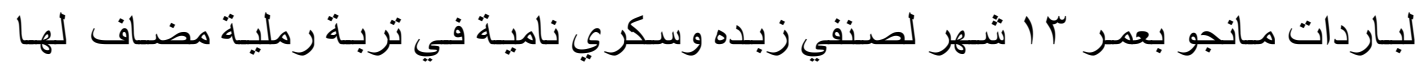
كربونـات كالسـيوم (CaCO

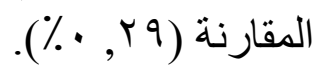

لوحظ اختلاف قدرة صنفي المـانجو المختبرين على تحمل النمو في التربة الجيرية النية

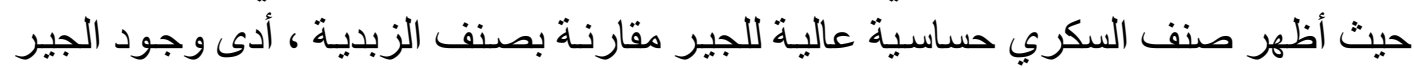

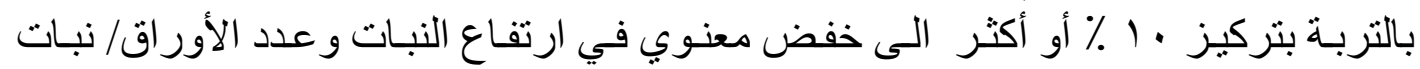

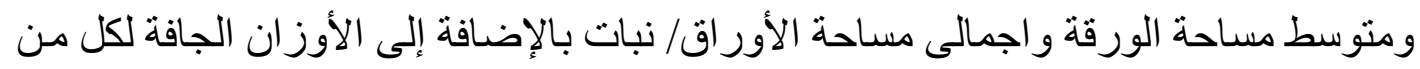

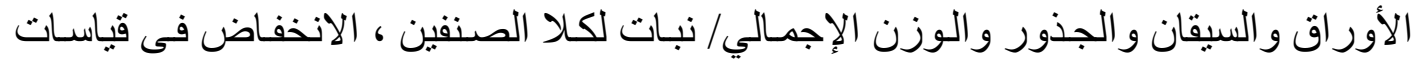

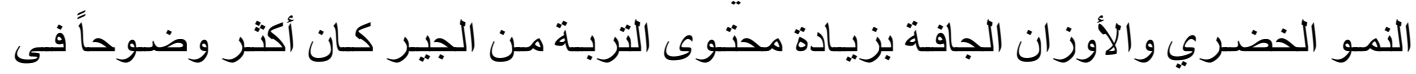

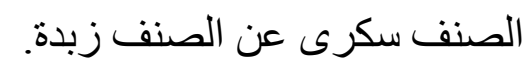

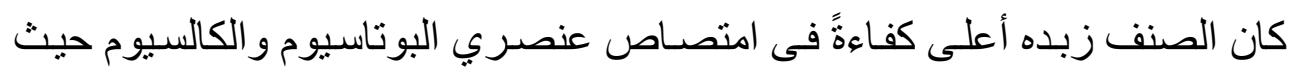

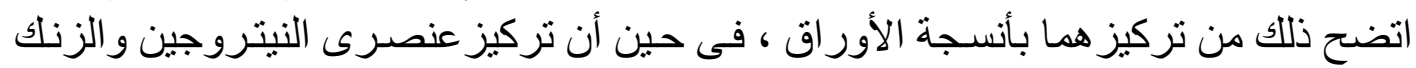

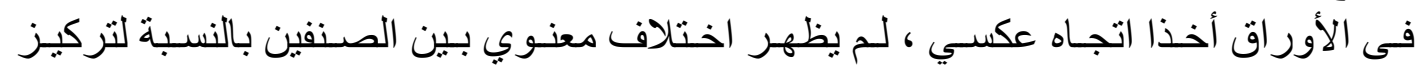
عنصري الفسفور والحديد التبالأوراق.

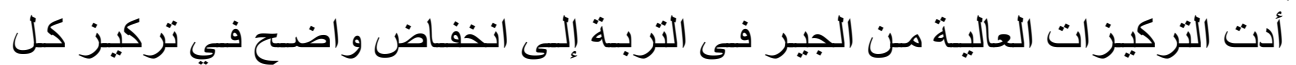

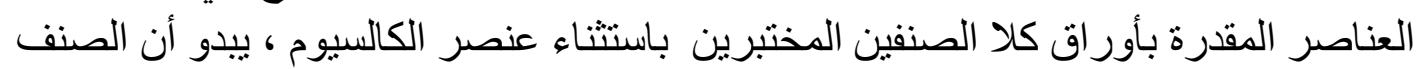

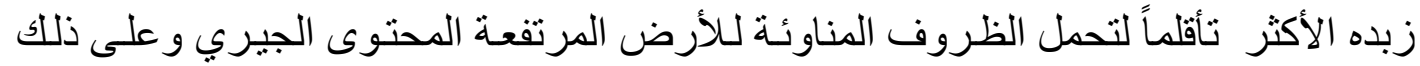

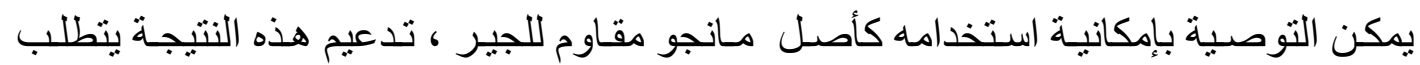

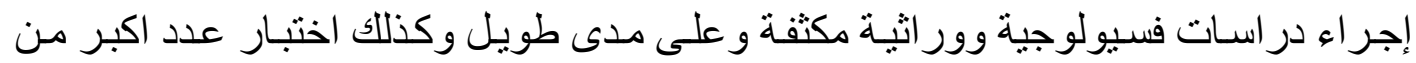
أصناف المانجو تحت مستوى أوسع من الظروف الطية الحقلية. 